Indonesian Journal of
Mathematics and Natural Sciences Education
p-ISSN: 2721-172X e-ISN: 2721-1746
Vol. 1 No.3 Th 2020; hal 182 -192
http://mass.iain-jember.ac.id

\title{
Etnomatematika dalam Perspektif Budaya Madura
}

\author{
Darwis Abroriy ${ }^{*}$ \\ ${ }^{1}$ SMP Nazhatut Thullab, Kec. Camplong, Kab. Sampang \\ * E-mail: pulaubiru.14@gmail.com
}

\begin{abstract}
Abstrak
Etnomatematika merupakan salah satu wujud pengintegrasian karakter dan literasi dalam pembelajaran matematika. Melaui pendekatan etnomatematika, pembelajaran matematika di sekolah menggunakan media berupa budaya yang ada disekitar lingkungan siswa. Praktik budaya dalam masyarakat memungkinkan tertanamnya konsep, ide dan aktifitas matematika seperti menghitung/ membilang, mengukur, mengelompokkan, merancang bangun, dan lain sebagainya.

Penelitian ini merupakan penilitian kualitatif dengan menggunakan pendekatan etnografi, yang bertujuan untuk memperoleh deskripsi dan analisis mendalam tentang konsep-konsep matematika dalam budaya Madura melalui penelitian lapangan.

Berdasarkan hasil penelitian, dapat dipahami bahwa dalam budaya Madura terdapat berbagai hal yang mengandung ide/ konsep matematika. Selain itu dalam budaya yang ada di Madura juga menunjukkan adanya hubungan etnomatematika dengan konsep-konsep matematika.
\end{abstract}

Kata Kunci: Budaya, Ethnomatematika, Madura

\section{PENDAHULUAN}

Perkembangan Ilmu Pengetahuan dan Teknologi (IPTEK) yang semakin pesat, memberikan kontribusi yang cukup besar dalam mengembangkan teknologi pendidikan. Inovasi dalam bidang pendidikan juga mengalami perkembangan yang pesat. Telah banyak upaya yang dilakukan oleh pemerintah untuk menunjang terhadap inovasi pendidikan, salah satunya yakni dengan adanya penataan kembali kurikulum pendidikan mulai dari pendidikan dasar sampai pendidikan tinggi.

Pada kurikulum 2013 dipendidikan dasar dan menengah, terdapat dua hal yang harus diintegrasikan dalam pelaksanaannya yaitu pendidikan karakter dan literasi (Kemendikbud, 2018). Pengintegrasian pendidikan karakter dan literasi dalam kurikulum dapat dilakukan mulai dari proses penyusun kurikulum satuan pendidikan, pelaksanaan kegiatan pembelajaran, hingga tahap evaluasi di satuan pendidikan (Apandi, 2018). Melalui pengintegrasian pendidikan karakter dan literasi dalam kegiatan pembelajaran, dunia pendidikan senantiasa akan mampu menciptakan SDM bangsa Indonesia yang unggul dan siap dengan tantangan perkembangan zaman. Langkah yang diambil oleh pemerintah melalui penataan kurikulum ini senantiasa perlu 
didukung oleh seluruh komponen pendidikan mulai dari pemerintah pusat sampai daerah, termasuk oleh satuan pendidikan.

Salah satu bentuk pengintegrasi pendidikan karakter dan literasi dalam pembelajaran yakni dengan melibatkan unsur budaya, khususnya kearifan lokal dalam pembelajaran di sekolah. Sehingga peserta didik nantinya bisa menjadi generasi yang berkarakter dan mampu menjaga serta melestarikan budaya sebagai landasan karakter bangsa. Penanaman nilai budaya penting untuk dilakukan sejak dini pada setiap individu. Sehingga setiap individu mampu lebih memahami, memaknai, dan menghargai serta menyadari akan pentingnya nilai budaya dalam menjalankan setiap aktivitas kehidupan (Fajriyah, 2018).

Praktik budaya dapat memungkinkan tertanamnya berbagai konsep bidang keilmuan, termasuk juga konsepkonsep matematika. Wahyuni (2016) menyatakan bahwa matematika merupakan produk budaya dengan hasil berupa abstraksi pikiran manusia, serta sebagai alat memecahkan masalah. Dalam suatu budaya dapat tercipta berbagai ide matematis sesuai dengan bentuk budaya yang ada di lingkungan tersebut. Oleh karena itu kajian matematika dalam budaya sangat dibutuhkan, karena matematika merupakan konstruksi sosial-budaya, produk budaya, dan terkandung dalam budaya (Ernest dalam Fajriyah, 2018).

Pengintegrasian budaya dalam pembelajaran matematika dikenal dengan istilah etnomatematika. Dalam etnomatematika, pembelajaran tentang matematika menggunakan perspektif budaya yang terkait dengan berbagai aktivitas matematika seperti mengelompokkan, berhitung, mengukur, merancang bangun, bermain, menentukan lokasi dan lain sebagainya. Hal ini sesuai dengan pendapat D'Ambrosio (dalam Dominikus dkk, 2014) yang menyatakan bahwa etnomatematika adalah matematika yang dipraktekkan diantara kelompok budaya, seperti masyarakat, kelompok buruh, anak-anak dari kelompok usia tertentu bahkan sampai sekelas professional. Lebih lanjut D'Ambrosio juga mengungkapkan bahwa tujuan dari etnomatematika adalah untuk menunjukkan bahwa dalam mengiterpretasikan matematika terdapat berbagai macam cara dengan mempertimbangkan pengetahuan matematika sekolah yang dikembangkan melalui berbagai sektor masyarakat, serta dengan mempertimbangkan berbagai budaya yang mengandung praktik matematika.

Istilah ethnomathematis yang selanjutnya dikenal dengan etnomatematika, pada awalnya mengacu pada praktik matematika yang dilakukan oleh masyarakat buta huruf dan praktik matematika dalam budaya tanpa adanya ekspresi tertulis dari masyarakat kuno (D'Ambrosio dalam Dominikus dkk, 2017). Dalam hal ini D'Ambrosio menekankan bahwa fokus etnomatematika berawal pada masyarakat yang kurang atau bahkan tidak pernah belajar matematika di pendidikan formal maupun non formal. Selanjutnya D'Ambrosio memperluas cakupan makna budaya dalam etnomatematika sehingga mendefinisikan etnomatematika yaitu matematika yang dipraktekkan di antara kelompok budaya 
seperti masyarakat nasional suku, kelompok buruh, anak-anak dari kelompok usia tertentu dan kelas profesional (D'Ambrosio dalam Dominikus dkk, 2017).

Sementara itu, Kucuk (2014) mengungkapkan bahwa entomatematika merupakan istilah yang digunakan untuk menjelaskan hubungan antara budaya dengan matematika. Barton (dalam Hurit \& Suwarsono, 2019) mengungkapkan bahwa etnomatematika juga dapat diistilahkan sebagai sebuah program dengan tujuan untuk mempelajari bagaimana siswa agar dapat memahami, mengartikulasikan, dan mengolah sehingga pada akhirnya dapat menggunakan ide-ide matematika, konsep, dan praktiknya dalam memecahkan masalah yang berkaitan dengan aktivitas sehari-hari.

Berdasarkan definisi tentang etnomatematika di atas, dapat dipahami bahwa etnomatematika adalah ide-ide atau praktik matematika yang dilakukan oleh berbagai kelompok budaya seperti kelompok buruh, kelompok masyarakat baik dari anak-anak maupun pada usia tertentu, masyarakat adat dan lain sebagainya.

Etnomatematika sebagai suatu pendekatan pembelajaran, akan membuat lingkungan belajar menjadi menyenangkan. Siswa dapat terlibat aktif di kelas karena mereka belajar berdasarkan budaya yang sudah mereka kenal sebelumnya. Sehingga hasil belajar dan tujuan pembelajaran dapat tercapai dengan lebih baik. Selain itu melalui etnomatematika juga membantu mengembangkan pemahaman siswa tentang budaya, khususnya budaya khas di daerahnya masing-masing.
Di samping itu, hasil studi PISA (Programme for International Student Assessment) menunjukkan bahwa ratarata siswa Indonesia kurang mampu menggunakan konsep matematika untuk menyelesaikan soal yang berhubungan dengan kehidupan seharihari (Stacey, 2011). Selain itu terkadang siswa dalam menyelesaikan soal matematika cenderung hanya dengan pola trial dan error (Zayadi \& Kurniati, 2018).

Penelitian terdahulu terkait etnomatematika sudah banyak dilakukan. Diantaranya penelitian (Sarwoedi, dkk. 2018) yang mengungkapkan bahwa pembelajaran matematika berbasis etnomatematika, efektif dalam meningkatkan kemampuan pemahaman matematika siswa. Selain itu juga terdapat hasil penelitian Charitas \& Prahmana (2018) yang meneliti tentang eksplorasi aktivitas matematika pada kegiatan merancang desain kebaya kartini. Sementara itu Febriyanti, Prasetya, \& Irawan (2018) juga melakukan penelitian etnomatematika pada permainan tradisional engklek dan gasing khas budaya sunda. Hayuhantika \& Dwi (2019) dalam penelitiannya mengungkapkan bahwa etnomatematika sebagai suatu jembatan antara matematika dan budaya memberikan pengalaman pembelajaran yang lebih bermakna bagi siswa.

Dari pembahasan tersebut di atas, penulis akan mengeksplorasi ide-ide matematika pada berbagai budaya yang ada di Madura. Dengan harapan dapat menjadi suatu langkah alternatif, baik dalam meningkatkan motivasi belajar siswa, dan meningkatkan pemahaman siswa baik pada konsep matematika 
maupun dalam pelestarian budaya Madura.

\section{METODE}

Penelitian ini merupakan penelitian kualitatif dengan menggunakan pendekatan etnografi, yang bertujuan untuk memperoleh deskripsi dan analisis mendalam tentang objek penelitian (Moleong, 2018). Dalam penelitian ini objek yang dimaksud adalah konsep-konsep matematika dalam budaya Madura melalui penelitian lapangan. Penelitian ini dilakukan mulai bulan Juli 2020.

Dalam penelitian ini, instrumen penelitiannya adalah human instrument, yaitu peneliti berperan sebagai instrumen utama. Data dan informasi yang diperoleh dari literatur, observasi, dokumentasi dan wawancara, dideskripsikan untuk dianalisis lebih lanjut. Dalam hal ini, peneliti berhubungan langsung dengan penelitian dan berperan sebagai pengumpul data melalui pengumpulan data pustaka, wawancara, observasi dan dokumentasi.

\section{HASIL DAN PEMBAHASAN}

\section{ETNOMATEMATIKA DAN PEMBELAJARAN MATEMATIKA}

Salah satu pendekatan pembelajaran yang berkembang saat ini adalah pembelajaran berbasis budaya. Pada pendekatan pembelajaran ini, aktivitas pembelajaran lebih mengutamakan pada aktivitas siswa dengan berbagai ragam latar belakang budaya yang dimiliki. Pada pembelajaran berbasis budaya, pendekatan yang dapat dilakukan dapat dibagi menjadi 3 (tiga) yaitu belajar tentang budaya, belajar dengan budaya, dan belajar melalui budaya (Ekowati, dkk, 2017).

Dalam kaitannya dengan pembelajaran berbasis budaya, etnomatematika dapat dijadikan sebagai pendekatan pembelajaran matematika yang mengintegrasikan unsur-unsur budaya dalam proses pembelajaran, termasuk dalam hal penilaian hasil belajarnya. Melalui penerapan etnomatematika, guru dapat mewujudkan pembelajaran kontekstual dan bermakna tentang matematika. Sehingga etnomatematika sangat berpotensi untuk dikembangkan menjadi salah satu inovasi dalam pembelajaran kontekstual, khususnya dalam pembelajaran matematika.

Kajian etnomatematika dalam pembelajaran matematika dapat mencakup segala bidang seperti arsitektur, tenun, jahit, pertanian, tarian tradisional, permainan tradisional, kain batik, hubungan kekerabatan, ornamen, kegiatan spiritual dan lain sebagainya.

\section{ETNOMATEMATIKA DALAM BUDAYA MADURA}

Berikut ini penulis sajikan bentukbentuk etnomatematika serta ide-ide matematika dalam budaya masyarakat Madura.

1. Membilang dengan basis 10

Membilang merupakan salah satu aktifitas matematika yang sering digunakan oleh masyarakat (Karnilah dan Juandi, 2013). Demikian juga pada masyarakat Madura. Pada masyarakat Madura terdapat aktifitas membilang dengan menggunakan basis bilangan 10 . Adapun bilangan tersebut dijelaskan melalui tabel 1 berikut. 
Indonesian Journal of Mathematics and Natural Science Education, 1 (3), 2020

Tabel 1. Istilah Bilangan Basis 10 dalam Bahasa Madura

\begin{tabular}{cc}
\hline $\begin{array}{c}\text { Lambang } \\
\text { Bilangan }\end{array}$ & $\begin{array}{c}\text { Istilah Bahasa } \\
\text { Madura }\end{array}$ \\
\hline$(1)$ & $(2)$ \\
\hline 10 & Sa Jina \\
20 & Du Jina \\
30 & Tello Jina \\
40 & Empa' Jina \\
50 & Lema Jina \\
60 & Ennem Jina \\
70 & Pettong Jina \\
80 & Bellung Jina \\
90 & Sangang Jina \\
\hline
\end{tabular}

Penggunakan kata "Sa Jina" untuk bilangan 10 dan seterusnya tersebut, oleh masyarakat Madura hanya digunakan untuk kegiatan membilang dalam kaitannya menentukan jumlah suatu barang atau benda mati tertentu, serta benda hidup kecuali manusia. Selain itu, penggunakan kata imbuhan "Jina" dalam basis bilangan 10, hanya berhenti pada bilangan 90 (Sangang Jina). Namun disaat membilang barangbarang yang dimuliakan termasuk membilang jumlah banyaknya manusia, masyarakat Madura menggunakan istilah lain disajikan pada tabel 2.

Tabel 2. Istilah Lain Bilangan Basis 10 dalam Bahasa Madura

\begin{tabular}{cc}
\hline $\begin{array}{c}\text { Lambang } \\
\text { Bilangan }\end{array}$ & $\begin{array}{c}\text { Istilah Bahasa } \\
\text { Madura }\end{array}$ \\
\hline$(1)$ & $(2)$ \\
\hline 10 & Sa Polo \\
20 & Du Polo \\
30 & Tello Polo \\
40 & Empa' Polo \\
50 & Seket \\
60 & Sabidha' \\
70 & Pettong Polo \\
\hline
\end{tabular}

\begin{tabular}{cc}
\hline$(1)$ & $(2)$ \\
\hline 80 & Bellung Polo \\
90 & Sangang Polo \\
100 & Satos \\
Dst & \\
\hline
\end{tabular}

\section{Mengukur}

Kegiatan mengukur pada umumnya berkaitan dengan pajang, lebar dan tinggi. Pada masyarakat Madura, alat ukur alternatif yang digunakan hampir sama dengan yang digunakan oleh beberapa suku pada umumnya yakni dengan menggunakan jengkal ("kelan" dalam bahasa Madura), tapak tangan ("tebbha" dalam bahasa Madura), depa, langkah kaki ("tengka' dalam bahasa Madura).

Namun selain itu, pada masyarakat Madura yang bekerja sebagai petambak, mereka juga menggunakan jari untuk mengukur pasang surut air laut/ sungai. Hal ini digunakan oleh para petambak, untuk memproyeksikan kenaikan tertinggi air laut/sungai saat pasang, sehingga bisa mengantisipasi terhadap jebolnya tanggul tambak.

3. Peralatan Kesenian Tradisional

Pada peralatan kesenian tradisional Madura mengandung beberapa ide matematika, yang dapat digunakan oleh guru sebagai media pembelajaran. Berikut penulis sajikan beberapa ide matematika pada peralatan kesenian tradisional masyarakat Madura.

a. Karapan Sapi

Karapan sapi merupakah salah satu budaya khas Madura. Karapan sapi di Madura berupa perlombaan pacuan sapi, dimana untuk satu nomor pacuan terdiri dari 2 ekor sapi yang disatukan dengan menggunakan alat yang disebut dengan 


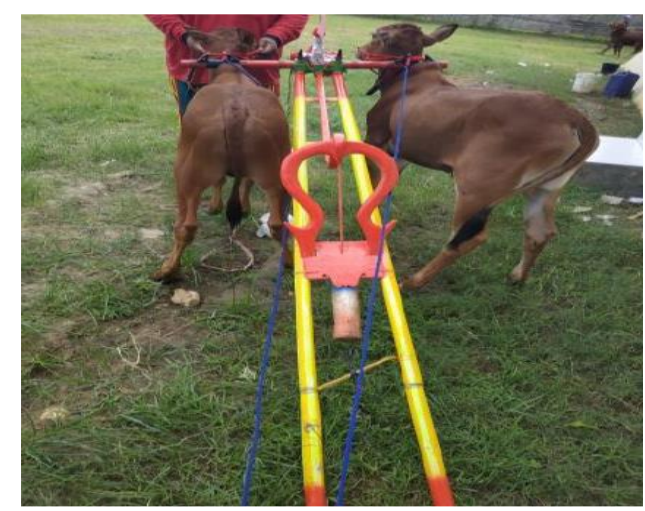

Gambar 1. “Kaleles” Karapan Sapi

"kaleles" (Aini, dkk., 2019). Pada alat "kaleles" (Gambar 1) ini terdapat berbagai konsep matematika, diantaranya konsep kesebangunan, konsep garis dan sudut, dan sebagainya.

b. "Saronen"

"Saronen" adalah alat musik tiup yang berbentuk kerucut memanjang dengan beberapa lubang berbentuk lingkaran yang berguna untuk memainkan dana (Gambar 2). Pada awalnya "saronen" merupakan me- kandungan konsep matematika seperti bangun datar (lingkaran), kerucut, dan sebagainya.

c. Kendang

Kendang (Gambar 3) merupakan alat musik tabuh/pukul. Pada masyarakat Madura gendang sering digunakan pada kesenian musik saat mengiringi acara "sandur" dan "tayub", yaitu suatu upacara ritual bagi petani atau nelayan untuk mengungkapkan rasa syukur kepada Tuhan Sang Pencipta (Arifah, 2013).

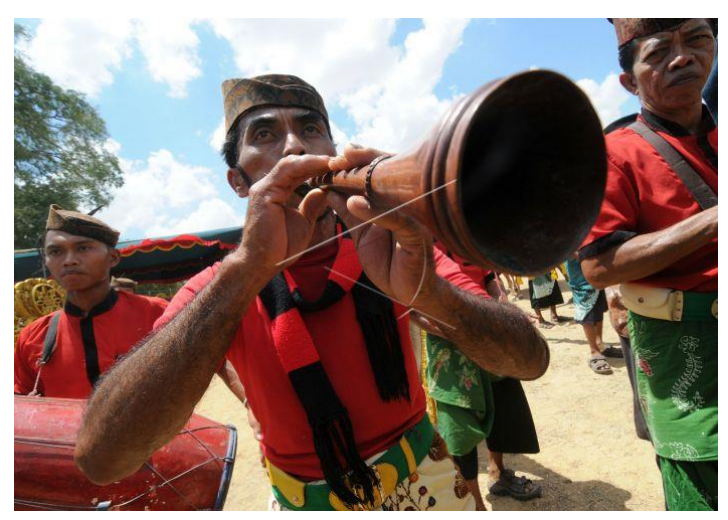

Gambar 2. Alat Musik "Sarnen"

dia dakwah dalam menyebarkan agama Islam. Namun pada perkembangannya "saronen" menjadi tradisi kesenian tersendiri. Saat ini "saronen" sering digunakan saat mengantarkan sapi yang akan ikut pacuan/ sapi ke garis start. Pada alat "saronen" ini terdapat beberapa
Pada peralatan gendang ini, terdapat beberapa konsep matematika seperti bangun datar (lingkaran dan belah ketupat), serta konsep bangun ruang.

d. Pesa'

Pesa' adalah sebutan bagi pakai khas laki-laki Madura (Gambar 4). Pada pakaian ini terdiri dari kaos yang 


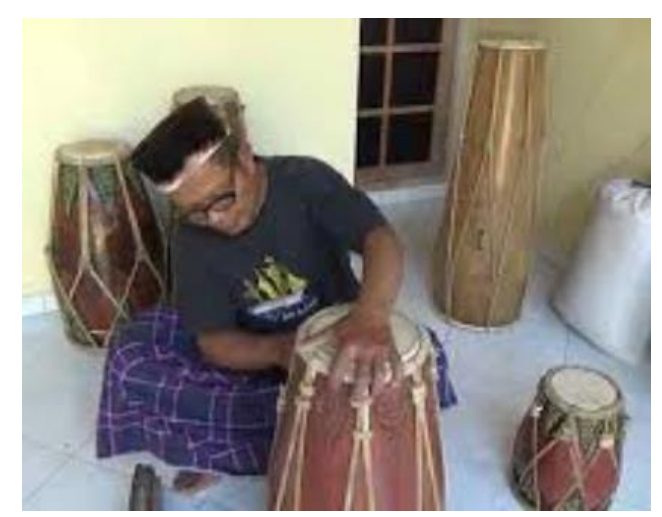

Gambar 3. Alat Musik Kendang

bermotif garis dengan warna merah dan putih yang dipadu-padankan dengan baju dan celana longgar berwarna hitam. Warna dan motif garis yang ada pada kaos pesa' memiliki makna ketegasan dan keberanian serta semangat kerja keras (Arifah, 2013). Konsep matematika yang terdapat pada pakai pesa' ini adalah konsep tentang garis-garis sejajar yang terdapat pada kaos pesa'. tersebut seperti bentuk lingkaran, garis lurus dan garis lengkung, simetris, refleksi, dilatasi, translasi, serta rotasi. Bahkan saat ini beberapa pembatik di Madura ada yang mengkreasikan motif batik dengan menggunakan beberapa gambar geometri dalam matematika.

5. Permainan Tradisional

a. Ta' Tanji

Pada permainan ini, pemain akan melompat dengan menggunakan

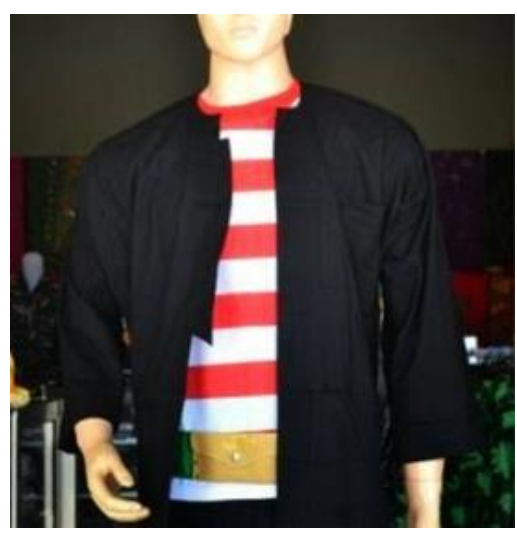

Gambar 4. Pakaian Pesa'

4. Motif Kain Batik

Hampir seluruh wilayah di Indonesia memiliki kerajinan batik dengan khas daerahnya masing-masing. Demikian juga dengan Madura yang memiliki kain batik yang khas dengan warna dan motif yang mencolok.

Konsep matematika pada kain batik terdapat pada pola/ motif batik satu kaki ke dalam gambar yang berupa gabungan dari beberapa bangun datar dalam konsep matematika (Gambar 5). Denah gambar tersebut sangat bervariasi, tergantung desain dan kreativitas para pemain. Termasuk juga bisa dibentuk seperti jaring-jaring bangun ruang tertentu. 


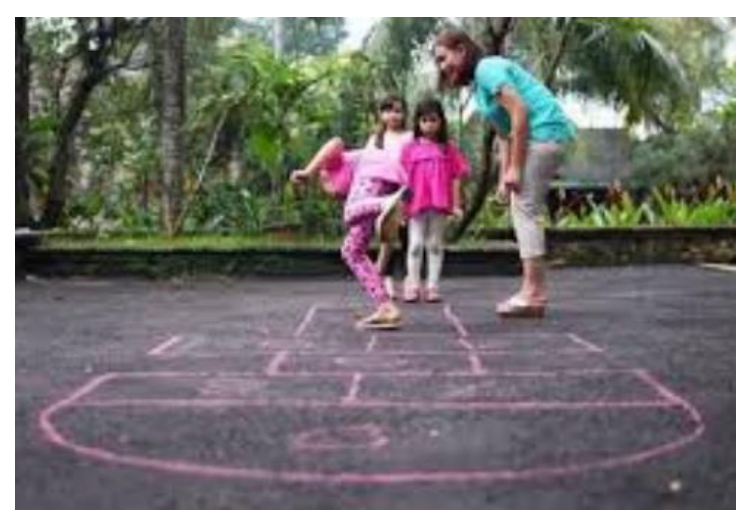

Gambar 5. Pakaian $T a^{\prime}$ Tanji

b. Pe Sapean

Pe Sapean adalah permainan tradisional Madura dengan bentuk menyerupai karapan sapi (Gambar 6). Hanya saja pada permainan pe sapean ini unsur sapi diganti dengan menggunakan roda yang dibuat dari sandal bekas. Untuk memainkan permainan ini, pemain harus memutar roda pada pe sapean dengan arah terbalik. Sehingga ketika dilepas, pe sapean tersebut akan bergerak maju (Pambudi, 2015). Selain konsep umum tentang bangun datar, dalam permainan ini juga
Selain permainan tersebut di atas, juga banyak permainan tradisional lainnya kemungkinan juga terdapat di daerah lain dan mengandung konsep matematika seperti : a. Hompimpa dan suit: konsep peluang; b. Beklen (bola bekel): konsep translasi, membilang, penjumlahan sertap engurangan pada bilangan bulat 1 sampai 5; c. Lompat tali: konsep garis lurus dan garis lengkung; d. Rem errem (petak umpet): konsep menghitung bilangan dari 1 s.d. 10; e. Dako (Dakon): konsep penjumlahan, pengurangan, perkalian dan pembagian pada bilangan bulat.

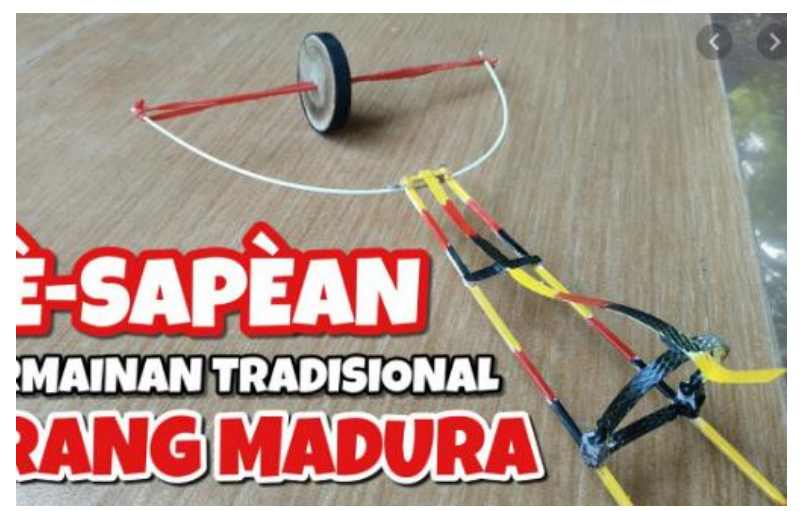

Gambar 6. Permainan Pe Sapean

terdapat konsep keliling lingkaran. Jarak yang dapat ditempuh oleh pe sapean akan sebanding dengan jumlah putaran dari roda pada pe sapean tersebut.
6. Timbunan Garam

Pulau Madura terkenal sebagai penghasil garam. Pada seluruh kabupaten yang ada di Madura, terdapat tempat untuk produksi garam. Pada 


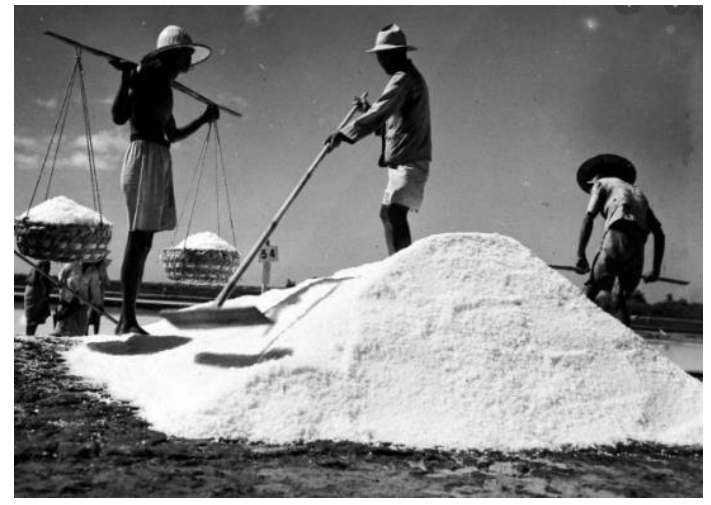

Gambar 7. Timbunan Garam

masyarakat tradisional, garam hasil panen akan ditumpuk disuatu tempat.

Konsep matematika yang terdapat pada tumpukan garam ini yaitu pada bentuk tumpukan yang menyerupai prisma (Gambar 7). Selain itu petani garam saat menumpuk garam menggunakan ukuran tertentu pada panjang, lebar serta tinggi tumpukannya. Sehingga petani tersebut juga akan mengetahui volume atau berat garam hasil panennya meskipun belum ditimbang.

\section{SIMPULAN}

Berdasarkan pembahasan diatas dapat dipahami bahwa terdapat berbagai konsep, ide dan aktifitas matematika dalam budaya, termasuk juga dalam budaya di Madura. Melalui pendekatan etnomatematika pada pembelajaran matematika dapat memberikan makna kontekstual bagi siswa. Dengan adanya bekal pengetahuan siswa tentang budaya yang ada di lingkungan sekitarnya, akan membangkitkan daya pikir siswa yang cepat tanggap dengan contoh nyata yang diambil sebagai studi kasus pada pembelajaran matematika.

Selain itu, dengan etnomatematika juga dapat menumbuh kembangkan motivasi dan semangat belajar siswa terhadap pelajaran matematika. Karena siswa menjadi benar-benar mengerti fungsi atau manfaat langsung ilmu matematika, serta implementasinya dalam kehidupan sehari-hari. Dan pada akhirnya dapat membuat kemampuan matematika siswa meningkat dalam pemecahan masalah.

Dengan pembelajaran matematika berbasis budaya (etnomatematika), akan memberikan dampak yang simultan bagi siswa dalam mengenal budayanya dan sekaligus belajar matematika. Para siswa akan semakin mereka menyenangi dan mencintai budayanya, sehingga budaya daerah dapat dilestarikan.

\section{DAFTAR PUSTAKA}

Aini, Z., Afifah, N., \& Hasanah, S.I. (2019). Etnomatematika dalam Keraben Sapeh Madura. Jounal of Medives : Journal of Mathematics Education IKIP Semarang. 3 (2): 177183

Apandi, I. (2018). Pengembangan Kurikulum Berbasis Karakter dan Literasi. https://www.kompasiana. com/idrisapandi/5aa5df0eab12ae28 050ecd72/ diakses tanggal pada tanggal 19 Juli 2020. 
Arifah, M. (2013). Mengenal Kesenian dan Kebudayaan Madura. https:/kompasiana.com/amp/mufti atinarifah. Diaskes pada tanggal 19 Juli 2020.

Charitas, R., \& Prahmana, I. (2018). Ethnomathematics: exploring the activities of designing kebaya kartini. MaPan : Jurnal Matematika Dan Pembelajaran. 6 (1): 10-19.

Dominikus, W.S., Nusantara, T., Subanji, \& Muksar, M. (2014). Ethnomathematics in Shifting Cultivation of Adonara Societty and Integration Within Curriculum of Primary Schools. Proceedings: The 1st Sriwijaya University Learning and Education International Conference (SULE-IC) 2014, Palembang: Sriwijaya University, May 16-18, 2014, D16-786 - D16-793.

Dominikus, W.S., Nusantara, T., Subanji, \& Muksar, M. (2017). Ethnomathematical Ideas in the Weaving Practice of Adonara Society in Indonesia. Journal of Mathematics and Culture. 11 (4): 83-95.

Ekowati, D W., Dian I K., \& Nawang S. (2017). Ethnomathematica dalam Pembelajaran Matematika. Jurnal Pemikiran dan Pengembangan SD. 5 (2): 716-721.

Fajriyah, E. (2018). Peran Etnomatematika Terkait Konsep Matematika dalam Mendukung Literasi. Prisma: Prossiding Seminar Nasional Matematika di Universitas Negeri Semarang. Semarang: 08 Januari 2018, 114-119.

Febriyanti, C., Prasetya, R., \& Irawan, A. (2018). Etnomatematika Pada
Permainan Tradisional Engklek dan Gasing Khas Kebudayaan Sunda. Barekeng: Jurnal Ilmu Matematika Dan Terapan. 12 (1): 1-6.

Hayuhantika, D., \& Dwi S.R. (2019). Eksplorasi Ide-ide Matematika Pada Kesenian Reog. Prismatika : Jurnal Pendidikan dan Riset Matematika. 2 (1): 1-14.

Hurin, R.U., \& Suwarsono. (2019). Kajian Etnomatematika Rumah Adat Kolo Bala di Kabupaten Flores Timur. Sendika : Prossiding. 5 (1): 308-316.

Karnilah, N., \& Juandi, D. (2013). Study Ethnomathematics: Pengungkapan Sistem Bilangan Masyarakat Adat Baduy. Jurnal online pendidikan matematika kontemporer. 1 (1): 213228.

Kemendikbud. (2018). Permendikbud Nomor 20 Tahun 2018 Tentang Penguatan Pendidikan Karakter Pada Satuan Pendidikan Formal. Jakarta : Kemendikbud

Kucuk, A. (2014). Ethnomathematics in Anatolia-Tukey: Mathematical Toughts in Multiculturalism. Revista Latinoamericana de Ethnomathematica. 7 (1): 171-184.

Moleong, L. (2018). Metodologi Penelitian Kualitatif. Bandung: PT. Remaja Rosda Karya.

Pambudi, B. (2015). Semiotika Karapan Sapi dan Transformasi Simbolik Masyarakat Madura. Jurnal Komunikasi Islam. 5 (1): 114-127.

Sarwoedi, Marinka, D.O., Febriani, P., \& Wirne, I.N. (2018). Efektifitas Etnomatematika dalam Meningkatkan Kemampuan Pemahaman Mate- 
matika Siswa Pendahuluan. Jurnal Pendidikan Matematika Raflesia. 3 (2): 171-176.

Stacey, K. (2011). The PISA View of Mathematical Literacy in Indonesia. Journal on Mathematics Education: 2 (2): 95-126.

Wahyuni, I. (2016). Eksplorasi Etnomatematika Masyarakat Pesisir Selatan Kecamatan Puger Kabupaten Jember. Fenomena. 15 (2): 225-238.

Zayadi, M., \& Kurniati, D. (2018). Mathematics reasoning and proving of students in generalizing the pattern. International Journal of Engineering \& Technology. 7 (2.10): 15-17.

\section{PROFIL SINGKAT}

Darwis Abroriy lahir di Sampang pada tanggal 07 Pebruari 1979. Gelar sarjana diperoleh pada tahun 2004 dengan konsentrasi akademik pendidikan matematika. Pada tahun 2014 mendapatkan kesempatan beasiswa melanjutkan study di Pascasarjana Universitas Negeri Malang pada prodi Pendidikan Matematika dan lulus tahun 2016 dengan gelar Magister Pendidikan.

Mulai tahun 2005 sampai sekarang berprofesi sebagai pendidik/ guru matematika di SMP Nazhatut Thullab Sampang. 